\title{
Recombination of Characters Between Mutant Stocks of Vibrio cholerae, Strain 162
}

\author{
BY K. BHASKARAN \\ Central Drug Research Institute, Lucknor, India
}

(Received 17 December 1959)

\section{SUMMARY}

Crosses between two mutant strains derived from Vibrio cholerae, one requiring valine and isoleucine and the other arginine and purine, yielded recombinants when seeded together on a minimal medium containing L-asparagine. Other markers such as resistance or sensitivity to streptomycin and a lytic choleraphage, which were unselected under the experimental conditions, also segregated in the recombinants.

\section{INTRODUCTION}

Previous studies (Bhaskaran, 1958, 1959) have shown that certain strains of Vibrio cholerae, when grown together in pairs, gave rise to recombinants which displayed characters derived from both parents. It was also shown that for this occurrence, a fertility factor (designated the $\boldsymbol{P}$ factor) should be present in either one or the other parent. This factor was first identified with $V$. cholerae, strain 129. The nature of the fertility factor was obscure but cells of strains possessing it $\left(\mathrm{P}^{+}\right.$strains) produced plaque-like clearings when tested on other strains devoid of this factor ( $\mathbf{P}^{-}$strains). The clearings resembled those produced by bacteriophages but unlike the latter, culture filtrates of $\mathrm{P}^{+}$strains did not produce clearings, i.e. contain free phage particles. The possibility that the substance responsible for the clearings produced by $\mathbf{P}^{+}$strains may be a bacteriocin has been suggested by Professor J. Lederberg (personal communication).

The $\mathbf{P}^{+}$character was infective, i.e. $\mathbf{P}^{-}$strains, suitably marked to ensure its subsequent recovery from mixed cultures, were rendered $\mathbf{P}^{+}$by growth with other $\mathbf{P}^{+}$strains. As culture filtrates of $\mathbf{P}^{+}$strains were unable to effect this infection it appeared that transfer of the $\boldsymbol{P}$ factor occurred between intact cells. Thus the $\boldsymbol{P}$ fertility factor in Vibrio cholerae was very similar to the fertility factor $F$ in the genetic system of Escherichia coli (Hayes, $1953 a$; Cavalli, Lederberg \& Lederberg, 1953), though $\mathrm{F}^{+}$strains of $\boldsymbol{E}$. coli do not produce clearings on $\mathrm{F}^{-}$strains. Crosses between two $\mathrm{P}^{-}$strains of $V$. cholerae are infertile as are crosses of two $\mathrm{F}^{-}$strains of $E$. coli.

The present communication deals with a study of genetic recombination in Vibrio cholerae employing mutant stocks derived from strain 162 with complementary nutritional dependencies and differing also in resistance to streptomycin and to a lytic choleraphage (phage 200 Lahiri). 


\section{METHODS}

Strains. A list of mutants of Vibrio cholerae, strain 162, and the technique employed for their isolation is given in Table 1 . The symbols used to denote the various mutant characters are those proposed by Dr M. Demerc for ' $a$ uniform nomenclature in bacterial genetics' (see Microbial Genetics Bulletin, 16, 38, 1958). It will be seen that the ilva mutant was isolated in a single step which indicates that its nutritional deficiencies, i.e. requirement for isoleucine and valine probably resulted from a single gene mutation.

\section{Table 1. Mutants of Vibrio cholerae, strain 162}

\begin{tabular}{|c|c|c|c|}
\hline Strain & Genotype & Origin & Technique employed for isolation \\
\hline 162 & pur str-s 200-s & Parent strain & - \\
\hline V 37 & arg pur str-s 200-s & 162 & Ultraviolet and penicillin (Davis, 1949) \\
\hline V 43 & arg pur str-r 200-s & V37 & Selection by streptomycin \\
\hline V 44 & arg pur str-r 200-r & V43 & Selection by phage 200 \\
\hline V 45 & arg pur str-s 200-r & V 37 & Selection by phage 200 \\
\hline $162 / p$ & pur ${ }^{+}$str-s 200-s & 162 & Selection on minimal medium \\
\hline V 39 & ilva str-s 200-s & $162 / p$ & Ultraviolet and penicillin \\
\hline $\mathbf{V} 40$ & ilva str-r 200-s & V 39 & Selection by streptomycin \\
\hline $\mathbf{V} 41$ & ilva str-r 200-r & V40 & Selection by phage 200 \\
\hline V 42 & ilva str-s 200-r & V 39 & Selection by phage 200 \\
\hline
\end{tabular}

Key. pur: purine requirement (present in wild type strain), satisfied by hypoxanthine; arg: arginine requirement; $i l v a$ : isoleucine + valine requirement; pur $^{+}$: purine not required; str-s : streptomycin sensitivity; str-r : streptomycin resistance; 200-s : phage 200 sensitivity; 200-r : phage 200 resistance.

Media. Nutrient broth and nutrient agar were prepared as described previously (Bhaskaran, 1958).

Recombination techniques. The technique employed in the past was to grow the parent strains together in broth for $18 \mathrm{hr}$. at $37^{\circ}$ and to seed a washed suspension of the mixture on a minimal medium (Bhaskaran \& Rowley, 1956) which selected non-exacting 'prototroph' recombinants. Results were negative if the preliminary growth of the mixed strains was omitted, although the period of incubation could be curtailed to $4 \mathrm{hr}$. without any significant reduction in the number of recombinants recovered. This technique was open to the criticism that the relative frequencies of the various recombinant classes may be influenced by the selective forces in the culture mixture. To obviate this it was necessary to seed washed suspensions of the parent strains directly on to a minimal medium and isolate recombinants produced by recombination in situ. As the minimal medium employed was not satisfactory for this purpose it was fortified with L-asparagine $(0.004 \%, w / v)$ as Fisher (1957) had shown that a dicarboxylic acid of the Krebs tricarboxylic acid cycle (or an immediate precursor) was essential for the energy required during conjugation and genetic exchange in Escherichia coli. This medium proved quite satisfactory and all the experiments recorded in this paper were carried out by direct seeding on minimal media containing L-asparagine.

For these experiments $10 \mathrm{ml}$. volumes of nutrient broth contained in $100 \mathrm{ml}$. Erlenmeyer flasks were seeded from overnight agar slant cultures of the strains individually. After $4 \mathrm{hr}$. incubation at $37^{\circ}$ without aeration the cultures were 
centrifuged at 2500 r.p.m. for $15 \mathrm{~min}$. and the supernatants were discarded. The bacterial deposits were resuspended in $1 \mathrm{ml}$. of minimal medium and employed in recombination tests. $0.1 \mathrm{ml}$. amounts of each culture were inoculated separately as controls, while $0.05 \mathrm{ml}$. amounts of each culture were mixed and spread on the surface of the minimal media for the isolation of recombinants. The plates were incubated at $37^{\circ}$ for $72 \mathrm{hr}$. and the colonies which appeared were counted and investigated further.

Study of recombinants. Colonies which appeared on recombination plates were subjected to three serial cultivations on the same medium as that on which they were isolated. This served to free them from parental contaminants and single colony isolations were not generally carried out. The purified recombinant colonies were then scored for streptomycin sensitivity by spotting on nutrient agar containing dihydrostreptomycin sulphate $(500 \mu \mathrm{g} . / \mathrm{ml}$.) and for sensitivity to phage 200 by streaking a phage suspension across a streak of the culture on nutrient agar.

\section{RESULTS}

Crosses were carried out between the ilva and the arg pur stocks of Vibrio cholerae, strain 162. Reverse mutations to single nutritional deficiencies were rare in the parent strains (see Table 2) so that every colony which appeared from a cross on a supplemented minimal medium could justifiably be regarded as a recombinant.

Table 2. Number of colonies on supplemented and unsupplemented minimal agar from arg pur and ilva mutants of Vibrio cholerae, strain 162, and from $\mathbf{P}^{-} \times \mathrm{P}^{-}$crosses

\begin{tabular}{|c|c|c|c|c|c|c|c|c|}
\hline \multirow{3}{*}{$\begin{array}{c}\text { Strain } \\
\text { arg pur str-s 200-s }\end{array}$} & \multirow{3}{*}{$\begin{array}{l}\quad \mathbf{P} \\
\text { polarity } \\
\mathbf{P}^{-}\end{array}$} & \multirow{3}{*}{$\begin{array}{c}\text { Expt. } \\
\text { no. } \\
1 \\
2\end{array}$} & \multicolumn{6}{|c|}{ Medium } \\
\hline & & & \multicolumn{2}{|c|}{ Minimal } & \multicolumn{2}{|c|}{$\underset{\text { purine* }}{\text { Minimal + }}$} & \multicolumn{2}{|c|}{$\begin{array}{c}\text { Minimal+ } \\
\text { arginine* }\end{array}$} \\
\hline & & & $\begin{array}{l}\text { Nil } \\
\text { Nil }\end{array}$ & $\begin{array}{l}\text { Nil } \\
\text { Nil }\end{array}$ & $\begin{array}{l}\text { Nil } \\
1\end{array}$ & $\begin{array}{l}1 \\
1\end{array}$ & $\begin{array}{l}2 \\
4\end{array}$ & $\begin{array}{l}\mathbf{2} \\
\mathbf{3}\end{array}$ \\
\hline arg pur str-r 200-r & $\mathbf{P}^{-}$ & $\begin{array}{l}\mathbf{1} \\
\mathbf{2}\end{array}$ & $\begin{array}{l}\text { Nil } \\
\text { Nil }\end{array}$ & $\begin{array}{l}\text { Nil } \\
\text { Nil }\end{array}$ & $\begin{array}{l}\text { Nil } \\
\text { Nil }\end{array}$ & $\begin{array}{l}\text { Nil } \\
\text { Nil }\end{array}$ & $\begin{array}{l}\text { Nil } \\
\text { Nil }\end{array}$ & $\begin{array}{l}\text { Nil } \\
\text { Nil }\end{array}$ \\
\hline ilva str-s $200-s$ & $\mathbf{P}^{-}$ & $\mathbf{2}$ & Nil & Nil & $\begin{array}{l}\text { Not } \\
\text { done } \\
\text { Not } \\
\text { done }\end{array}$ & $\begin{array}{l}\text { Not } \\
\text { done } \\
\text { Not } \\
\text { done }\end{array}$ & $\begin{array}{l}\text { Not } \\
\text { done } \\
\text { Not } \\
\text { done }\end{array}$ & $\begin{array}{c}\text { Not } \\
\text { done } \\
\text { Not } \\
\text { done }\end{array}$ \\
\hline ilva str-r 200-r & $\mathbf{P}^{-}$ & 2 & Nil & Nil & $\begin{array}{l}\text { Not } \\
\text { done } \\
\text { Not } \\
\text { done }\end{array}$ & $\begin{array}{c}\text { Not } \\
\text { done } \\
\text { Not } \\
\text { done }\end{array}$ & $\begin{array}{l}\text { Not } \\
\text { done } \\
\text { Not } \\
\text { done }\end{array}$ & $\begin{array}{l}\text { Not } \\
\text { done } \\
\text { Not } \\
\text { done }\end{array}$ \\
\hline $\begin{array}{l}\text { arg pur str-s 200-s } \times \\
\text { ilva str-r 200-r }\end{array}$ & $\begin{array}{l}\mathbf{P}^{-} \times \mathbf{P}^{-} \\
\text {cross }\end{array}$ & $\begin{array}{l}1 \\
2\end{array}$ & $\begin{array}{l}\text { Nil } \\
\text { Nil }\end{array}$ & $\begin{array}{l}\text { Nil } \\
\text { Nil }\end{array}$ & $\begin{array}{l}\text { Nil } \\
\text { Nil }\end{array}$ & $\begin{array}{l}\text { Nil } \\
\text { Nil }\end{array}$ & $\begin{array}{l}\mathbf{1} \\
\mathbf{3}\end{array}$ & $\begin{array}{l}\text { Nil } \\
\mathbf{3}\end{array}$ \\
\hline $\begin{array}{l}\text { arg pur str-r } 200-r \times \\
\text { ilva str-s } 200-s\end{array}$ & $\begin{array}{c}\mathbf{P}^{-} \times \mathbf{P}^{-} \\
\text {cross }\end{array}$ & $\begin{array}{l}1 \\
\mathbf{2}\end{array}$ & $\begin{array}{l}\text { Nil } \\
\text { Nil }\end{array}$ & $\begin{array}{l}\text { Nil } \\
\text { Nil }\end{array}$ & $\begin{array}{l}\text { Nil } \\
\text { Nil }\end{array}$ & $\begin{array}{l}\mathbf{I} \\
\text { Nil }\end{array}$ & $\begin{array}{l}\text { Nil } \\
\text { Nil }\end{array}$ & $\begin{array}{l}\text { Nil } \\
\text { Nil }\end{array}$ \\
\hline
\end{tabular}

* Purine (hypoxanthine) and arginine were added to give a final concentration of $0.05 \%(w / v)$. $5 \times 10^{8}$ cells of each parent strain were seeded together on each plate in crosses and $10^{9}$ cells of each strain individually in other tests.

Figures represent colony counts on duplicate plates. 
Details of experiments carried out to show the infertility of $\mathrm{P}^{-} \times \mathrm{P}^{-}$crosses are also given in Table 2. As the strains were initially $\mathbf{P}^{-}$it was possible to carry out crosses after rendering either parent $\mathrm{P}^{+}$. Crosses were also carried out with the str, 200 markers reversed in the parent strains. Thus four crosses were possible; for details see Table 3.

Table 3. Numbers of recombinant colonies from crosses between arg, pur and ilva mutants of Vibrio cholerae, strain 162, on supplemented and unsupplemented minimal agar

\begin{tabular}{|c|c|c|c|c|c|}
\hline \multirow[b]{2}{*}{ Medium } & \multirow{2}{*}{$\begin{array}{l}\text { Parents } \\
\text { Cross Number } \\
\text { P polarity } \\
\text { Expt. no. }\end{array}$} & \multicolumn{2}{|c|}{$\begin{array}{c}\text { arg pur str-r 200-r } \\
\times \\
\quad \text { ilva str-s 200-s }\end{array}$} & \multicolumn{2}{|c|}{$\begin{array}{c}\text { arg pur str-s 200-s } \\
\times \\
\text { ilva str-r 200-r }\end{array}$} \\
\hline & & $\mathbf{P}^{+} \times \mathbf{P}^{-}$ & $\mathbf{P}^{-} \stackrel{\mathbf{2}}{\times} \mathbf{P}^{+}$ & $\mathbf{P}^{+} \stackrel{\mathbf{3}}{\times} \mathbf{P}^{-}$ & $\mathbf{P}^{-} \stackrel{4}{\times} \mathbf{P}^{+}$ \\
\hline Minimal & $\begin{array}{l}1 \\
2\end{array}$ & $\begin{array}{l}20,25 \\
44,33\end{array}$ & $\begin{array}{l}1,2 \\
14,4\end{array}$ & $\begin{array}{l}18,13 \\
21,17\end{array}$ & $\begin{array}{l}\text { Nil, Nil } \\
\text { Nil, Nil }\end{array}$ \\
\hline Minimal + purine* & $\begin{array}{l}2 \\
3\end{array}$ & $\begin{array}{c}207,176 \\
\text { pur } 44 \% \\
320,270 \\
\text { pur } 22 \% \\
186,154 \\
\text { pur } 43 \%\end{array}$ & $\begin{array}{c}166,200 \\
\text { pur } 86 \% \\
286,332 \\
\text { pur } 98 \% \\
\text { Not done }\end{array}$ & $\begin{array}{c}228,280 \\
\text { pur } 92 \% \\
88,100 \\
\text { pur } 88 \% \\
232,244 \\
\text { pur } 92 \%\end{array}$ & $\begin{array}{l}258,262 \\
\text { pur } 100 \% \\
310,270 \\
\text { pur } 100 \% \\
\text { Not done }\end{array}$ \\
\hline Minimal + arginine* & $\begin{array}{l}1 \\
2\end{array}$ & $\begin{array}{l}15,11 \\
\arg \text { nil } \\
8,9 \\
\arg 24 \% \\
22,17 \\
\arg 3 \%\end{array}$ & $\begin{array}{l}57,117 \\
\arg 100 \% \\
48,36 \\
\text { arg } 94 \% \\
\text { Not done }\end{array}$ & $\begin{array}{l}32,80 \\
\arg 78 \% \\
47,52 \\
\arg 42 \% \\
22,36 \\
\arg 34 \%\end{array}$ & $\begin{array}{l}51,44 \\
\text { arg } 98 \% \\
27,67 \\
\text { arg } 100 \% \\
\text { Not done }\end{array}$ \\
\hline Minimal + valine* & 2 & $\begin{array}{l}40,32 \\
\text { val nil } \\
36,55 \\
\text { val nil }\end{array}$ & $\begin{array}{l}\text { 1, nil } \\
\text { val nil }\end{array}$ & $\begin{array}{l}13,26 \\
\text { val nil } \\
19,23 \\
\text { val nil }\end{array}$ & Nil, Nil \\
\hline
\end{tabular}

$5 \times 10^{8}$ cells of each parent strain were seeded together on each plate: the figures represent colony counts on duplicate plates. The percentages of pur and arg colonies were calculated after testing 50 to 100 colonies from each cross on the supplemented media. When the total number of colonies was less than $\mathbf{5 0}$, all the colonies were tested.

* Purine (hypoxanthine), arginine and valine were added to give a final concentration of $0.05 \%(w / v)$.

In each experiment recombinants were isolated on minimal medium and also on minimal medium supplemented with a single nutritional factor, i.e. purine, arginine, valine or isoleucine. This study would show the relative frequency of the various recombination classes in respect of the unselected markers str, 200 and arg or pur under the same conditions of test.

It will be seen from Table 3 that no val recombinants were isolated from any of the four crosses, as all colonies which appeared on valine supplemented media were prototrophs. Tests with isoleucine media (not included in the table) also yielded only prototrophic recombinants. This was not unexpected as it was obvious by the very isolation of the ilva mutant that its two nutritional deficiencies were governed by the same locus. 
The occurrence of prototrophic recombinants was significantly influenced by $P$ polarity. ilva $\mathrm{P}^{+} \times$arg pur $\mathrm{P}^{-}$crosses (crosses 2 and 4, Table 3) yielded few prototrophs when compared to the same cross reversed with respect to $P$ (crosses 1 and 3, Table 3). pur recombinants were significantly more numerous on media supplemented with purine than were prototrophs on the same medium or on unsupplemented minimal media. (Cross 1 was to some extent an exception to this as prototrophs were more frequent than pur recombinants. arg recombinants were also few in this cross.) This indicated that pur and arg segregated independently.

Table 4. Segregation of str and 200 in recombinants arising from various parental combinations

Parents ... arg pur str-r 200-r $\times$ ilva str-s 200-s arg pur str-s 200-s $\times$ ilva str-r 200-r

\begin{tabular}{|c|c|c|c|c|c|}
\hline \multirow{2}{*}{$\begin{array}{l}\text { Recombinant } \\
\text { class }\end{array}$} & Cross number & ber & \multirow{2}{*}{$\frac{\mathbf{2}}{\mathbf{P}^{-} \times \mathbf{P}^{+}}$} & \multirow{2}{*}{$\frac{\mathbf{3}}{\mathbf{P}^{+} \times \mathbf{P}^{-}}$} & \multirow{2}{*}{$\frac{4}{\mathbf{P}^{-} \times \mathbf{P}^{+}}$} \\
\hline & P polarity & $\mathbf{P}^{+} \times \mathbf{P}^{-}$ & & & \\
\hline \multicolumn{6}{|c|}{ pur $^{+}$arg $^{+} i l v a^{+}$Expt. no. } \\
\hline- & 1 & 142 str-s 200-s & 10 str-s 200-s & $\begin{array}{r}74 \text { str-r } 200-r \\
1 \text { str-s } 200-s \\
1 \text { str-s } 200-r\end{array}$ & - \\
\hline & 2 & $\begin{array}{r}152 \text { str-s } 200-s \\
1 \text { str-r } 200-s\end{array}$ & $\begin{array}{r}16 \text { str-s } 200-s \\
4 \text { str-r } 200-r \\
1 \text { str-r } 200-s\end{array}$ & $\begin{array}{rrr}114 & \text { str-r } & 200-r \\
1 & \text { str-s } & 200-s \\
1 & \text { str-r } & 200-s \\
1 & \text { str-s } & 200-r\end{array}$ & - \\
\hline & 3 & 94 str-s 200-s & Not done & $\begin{array}{r}34 \text { str-r 200-r } \\
2 \text { str-r 200-s } \\
1 \text { str-s } 200-r\end{array}$ & Not done \\
\hline \multirow[t]{3}{*}{ pur arg ${ }^{+} i l v a^{+}$} & 1 & 22 str-s 200-s & $\begin{array}{r}36 \text { str-r 200-r } \\
5 \text { str-s 200-s } \\
2 \text { str-r } 200-s\end{array}$ & $\begin{array}{c}43 \text { str-s } 200-s \\
2 s t r-r 200-r \\
-\end{array}$ & $\begin{array}{c}47 \text { str-s } 200-s \\
-\end{array}$ \\
\hline & 2 & 10 str-s $200-s$ & 49 str-r 200-r & $\begin{array}{r}55 \text { str-s } 200-s \\
12 \text { str-r } 200-r \\
1 \text { str-s } 200-r \\
2 \text { str-r } 200-s\end{array}$ & $\begin{array}{c}49 \text { str-s 200-s } \\
1 \text { str-r 200-s } \\
-\end{array}$ \\
\hline & $\mathbf{8}$ & $\begin{array}{r}40 \text { str-s } 200-s \\
3 \text { str-r } 200-s\end{array}$ & Not done & $\begin{array}{r}42 \text { str-s } 200-s \\
3 \text { str-r } 200-r \\
1 \text { str-r } 200-s\end{array}$ & Not done \\
\hline \multirow[t]{3}{*}{$\arg$ pur $^{+} i l v a^{+}$} & 1 & - & $\begin{array}{r}49 \text { str-r 200-r } \\
1 \text { str-s 200-r }\end{array}$ & $\begin{array}{r}\text { 37 str-s 200-s } \\
1 \text { str-r 200-s }\end{array}$ & $\begin{array}{r}45 \text { str-s } 200-s \\
1 \text { str-r } 200-r \\
2 \text { str-r } 200-s\end{array}$ \\
\hline & 2 & 一 & & $\begin{array}{r}30 \text { str-s 200-s } \\
1 \text { str-r 200-r }\end{array}$ & $\begin{array}{r}49 \text { str-s } 200-s \\
1 \text { str-r } 200-s\end{array}$ \\
\hline & $\mathbf{3}$ & - & Not done & 17 str-s 200-s & Not done \\
\hline
\end{tabular}

Figures represent the number of colonies examined.

Table 4 presents an analysis of recombinants, isolated from crosses recorded in Table 3, with respect to the unselected markers str and 200. It will be seen that the vast majority of prototrophs (636 out of 650 colonies) from all the crosses yielding prototrophs, i.e. crosses, 1, 2 and 3, had the str, 200 markers of the ilva parent irrespective of its $\mathbf{P}$ polarity. This suggests that these characters segregated together with the $\arg ^{+}$and pur $^{+}$markers of the ilva parent and probably occupied a place between them in the chromosome.

The segregation of str, 200 markers in pur and arg recombinants was peculiar. In crosses 2 and 4 (Table 4) which are alike as regards $P$ polarity of the parent 
strains and differ only in the str, 200 markers of the parents, arg and pur recombinants generally resembled the arg pur parent as regards str, 200 markers. When crosses 1 and 3 (Table 4) are similarly compared it will be seen that in cross 1 , the pur recombinants generally resembled the ilva parent in str, 200 markers, while in cross 3 the resemblance was with the arg pur parent. As already observed, arg recombinants were few in cross 1 and could not be examined in sufficient numbers. arg recombinants of cross 3 were, however, similar to the pur recombinants of the same cross in possessing the str, 200 markers of the arg pur parent.

This difference in the segregation of $s t r, 200$ markers between crosses 1 and 3 (Table 4) could not be explained and further experiments were carried out to study recombinants obtained from crosses between the parent strains in which str, 200 markers were introduced in different combinations (Table 5).

Table 5. Segregation of str and 200 in other crosses

\begin{tabular}{|c|c|c|c|c|c|}
\hline \multirow[b]{2}{*}{$\begin{array}{c}\text { Cross } \\
\text { no. }\end{array}$} & \multirow[b]{2}{*}{ Parents } & \multirow[b]{2}{*}{$\begin{array}{c}\text { Expt. } \\
\text { no. }\end{array}$} & \multirow{2}{*}{$\begin{array}{l}\text { Number of } \\
\text { colonies on } \\
\text { minimal } \\
\text { agar + purine }\end{array}$} & \multicolumn{2}{|c|}{ Recombinants } \\
\hline & & & & $\arg ^{+}$pur $^{+} i l v a^{+}$ & pur $\arg ^{+} i l v a^{+}$ \\
\hline 1 & $\begin{array}{l}\text { arg pur str-s 200-r } \mathbf{P}^{+} \times \\
\text {ilva str-r 200-s } \mathbf{P}^{-}\end{array}$ & 2 & $\begin{array}{c}180,182 \\
\text { pur } 50 \% \\
166,200 \\
\text { pur } 47 \%\end{array}$ & $\begin{array}{c}49 \text { str-r 200-s } \\
23 \text { str-r 200-s } \\
- \\
-\end{array}$ & $\begin{array}{r}46 \text { str-r } 200-s \\
4 \text { str-s } 200-r \\
19 \text { str-r } 200-s \\
9 \text { str-s } 200-r \\
1 \text { str-s } 200-s\end{array}$ \\
\hline 2 & $\begin{array}{l}\text { arg pur str-r 200-s } \mathbf{P}^{+} \times \\
\text {ilva str-s 200-r } \mathbf{P}^{-}\end{array}$ & $\begin{array}{l}1 \\
2\end{array}$ & $\begin{array}{c}\text { 188, } 222 \\
\text { pur } 72 \% \\
202,252 \\
\text { pur } 69 \%\end{array}$ & $\begin{array}{r}11 \text { str-s } 200-r \\
3 \text { str-s } 200-s \\
21 \text { str-s } 200-r \\
2 \text { str-s } 200-8 \\
2 \text { str-r } 200-s\end{array}$ & $\begin{array}{r}24 \text { str-r } 200-s \\
12 \text { str-s } 200-r \\
42 \text { str-r } 200-s \\
12 \text { str-s } 200-r \\
1 \text { str-r 200-r }\end{array}$ \\
\hline
\end{tabular}

Though the number of colonies examined in these experiments (Table 5) was fewer than in previous crosses it is significant that when the 200-r marker was introduced in the arg pur $\mathbf{P}^{+}$parent, $82 \%$ of pur recombinants had the unselected str, 200 markers of the ilva parent (like cross 1 , Table 4), while if the arg pur, $\mathrm{P}^{+}$ parent was $200-s$, only $26 \%$ of pur recombinants were like the ilva parent in the str, 200 markers (like cross 3, Table 4). This interesting observation requires further study to determine if the aberration in segregation pattern was consistently associated with phage 200 resistance in the arg pur $\mathrm{P}^{+}$parent.

A study of Tables 4 and 5 also reveals the fact that the str and 200 markers generally segregate together in the various recombinant classes (1595 colonies out of 1625 tested). Only 30 colonies show cross-overs between str and 200. This strongly suggests close linkage of the str, 200 loci in Vibrio cholerae, strain 162.

\section{DISCUSSION}

The occurrence of genetic recombination between two auxotrophic mutants of Vibrio cholerae, strain 162, is demonstrated by the isolation of recombinants employing selective minimal media in which neither parent strain will grow. The role of a fertility factor in this genetic system, the $\boldsymbol{P}$ factor (Bhaskaran, 1959), is emphasized and genetic exchange appears to result from cellular conjugation between parental cells. The simultaneous segregation of certain other unselected 
markers like resistance or sensitivity to streptomycin and phage 200 also renders this phenomenon different from DNA induced transformations (pneumococcus, Avery, McLeod \& McCarty, 1944; Haemophilus influenzae, Alexander \& Leidy, 1951) and phage-mediated transductions in Salmonella (Zinder \& Lederberg, 1952) in which only isolated characters are usually transferred.

As the strains used in crosses were all derived by distinct mutational steps from a common ancestor the marked characters are assumed to be allelic, though actual tests for allelism have not been carried out. The recombination data suggests close linkage of the loci controlling resistance to streptomycin and phage 200.

The role of the fertility factor $\boldsymbol{P}$ in this genetic system is as obscure as $\boldsymbol{F}$ in Escherichia coli. As in $\boldsymbol{E}$. coli, transfer of the $\boldsymbol{P}$ factor in Vibrio cholerae is independent of the other genetic markers and occurs far more frequently. All the recombinants examined so far are $\mathrm{P}^{+}$as shown by their associated lytic effects on $\mathbf{P}^{-}$strains as well as by their fertility in crosses with $\mathrm{P}^{-}$strains. No $\mathrm{P}^{-}$recombinants have so far been isolated.

In Escherichia coli, $\mathrm{F}^{+}$strains are regarded as gene donors contributing only segments of their chromosomes to $\mathrm{F}^{-}$strains which are regarded as gene acceptors (Hayes, 1953b). An alternative explanation has also been put forward which explains the aberrations in segregation as due to segmental elimination in the zygotes which occurs preferentially from the $\mathrm{F}^{+}$chromosome (Lederberg, 1955). The evidence so far available in the genetic system of Vibrio cholerae does not permit any speculation on this point and work is in progress to study the mechanism of this recombination.

It was reported earlier (Bhaskaran, 1959) that in certain inter-strain crosses in Vibrio cholerae, some prototrophic colonies obtained were unstable and consistently segregated a parental (auxotrophic) type and recombinants. Such unstable prototrophs which appeared to be made up, at least in part, of partial heterozygotes (heterogenotes) could be identified by their agglutinability with both Inaba and Ogawa ' $O$ ' antisera when the parent strains differed in antigenic type (either Inaba or Ogawa). In the present investigation only Ogawa type cultures were employed in crosses and the identification of persistent heterogenotes by agglutination tests was not possible. It was not feasible to examine all prototrophs obtained from crosses to see if any of them segregated parental auxotroph types. It is quite likely that such colonies, if present, might have been missed in this study.

Further work is indicated to ascertain the true nature of the $\boldsymbol{P}$ factor in Vibrio cholerae. However, it has been observed that this factor is rather unstable. From $\mathrm{P}^{+}$cultures maintained on nutrient agar slants for over three months it has consistently been possible to isolate $\mathbf{P}^{-}$variants. For the satisfactory maintenance of $\mathbf{P}^{+}$strains it is desirable to stock the cultures at $4^{\circ}$ in a refrigerator and to make weekly transfers to fresh media.

The author wishes to thank Dr B. Mukerji, Director, Central Drug Research Institute, Lucknow, for his interest and support. He is also indebted to Professor M. N. Lahiri, All India Institute of Hygiene and Public Health, Calcutta, for his gift of phage 200. This work was supported by a grant from the Indian Council of Medical Research. The assistance of Mr Santosh Paul is acknowledged. 


\section{REFERENCES}

Auexander, H. E. \& Leidy, G. (1951). Determination of inherited traits of $H$. influenzae by desoxyribonucleic acid fractions isolated from type-specific cells. J. exp. Med. 93, 345.

Avery, O. T., McLeod, C. M. \& McCarty, M. (1944). Studies on the chemical nature of the substance inducing transformation of pneumococcal types. Induction of transformation by a desoxyribonucleic acid fraction from pneumococcus type III. $J$. exp. Med. 79, 137.

Bhaskaran, K. (1958). Genetic recombination in Vibrio cholerae. J. gen. Microbiol. $19,71$.

Bhaskaran, K. (1959). Observations of the nature of genetic recombination in Vibrio cholerae. Indian J. med. Res. 47, 253.

Bhaskaran, K. \& Rowley, D. (1956). Nutritional studies on Vibrio cholerae. J. gen. Microbiol. 15, 417.

Cavalid, L. L., Lederberg, J. \& Lederberg, E. M. (1953). An infective factor controlling sex compatibility in Bacterium coli. J. gen. Microbiol. 8, 89.

DAvIs, B. D. (1949). The isolation of biochemically deficient mutants of bacteria by means of penicillin. Proc. nat. Acad. Sci., Wash. 35, 1.

Frsmer, K. W. (1957). The role of the Krebs cycle in conjugation in Escherichia coli. $J$. gen. Microbiol. 16, 120.

HAYes, W. (1953a). Observations on a transmissible agent determining sexual differentiation in Bacterium coli. J. gen. Microbiol. 8, 72.

HAYES, W. (1953b). The mechanism of genetic recombination in Escherichia coli. Cold. Spring Harb. Symp. quant. Biol. 18, 75.

Lederberg, J. (1955). Recombination mechanisms in bacteria. J. cell. comp. Physiol. 45, Suppl. 2, 75.

Zinder, N. D. \& Lederberg, J. (1952). Genetic exchange in Salmonella. J. Bact. 64, 679. 